\title{
Anticolon Cancer Activity of Zinc Oxide Nanoparticles Using Fresh Leaf Extract Nyctanthes Arbor-tristis
}

\section{R. Mathammal ( $\square$ mathammals_shanmugam@yahoo.com )}

Department of Physics, Sri Sarada College for Women (Autonomous), Salem-636 016, Tamil Nadu, India

\section{K. Shreema}

Narusu's Sarathy Institute of Technology, Salem-636 305, Tamilnadu, India

\section{R. Mekala}

Department of Physics, Sri Sarada College for Women (Autonomous), Salem-636 016, Tamil Nadu, India

\section{Kalaiselvi}

Department of Physics, Navarasam Arts \& Science College for Women, Erode, Tamilnadu, India.

\section{Sekar Vijayakumar}

Marine college, Shandong University, Weihai P.R. China-264209

\section{Research Article}

Keywords: Green synthesis, Zinc Oxide nanoparticles, Nyctanthes arbor-tristisis, XRD, FTIR, UV-Visible, SEM, EDX and anticancer activity

Posted Date: May 10th, 2021

DOl: https://doi.org/10.21203/rs.3.rs-492230/v1

License: (c) (1) This work is licensed under a Creative Commons Attribution 4.0 International License. Read Full License 


\title{
Anticolon cancer activity of Zinc Oxide Nanoparticles Using Fresh Leaf Extract Nyctanthes arbor-tristis
}

\author{
K.Shreema $^{1 *}$, R.Mekala ${ }^{2}$, R.Mathammal ${ }^{1}$, V.Kalaiselvi ${ }^{3}$, Sekar Vijayakumar ${ }^{4}$ \\ ${ }^{1}$ Department of Physics, Sri Sarada College for Women (Autonomous), Salem-636 016, Tamil Nadu, \\ India. \\ ${ }^{2}$ Narusu's Sarathy Institute of Technology, Salem-636 305, Tamilnadu, India \\ ${ }^{3}$ Department of Physics, Navarasam Arts \& Science College for Women, Erode, Tamilnadu, India. \\ ${ }^{4}$ Marine college, Shandong University, Weihai P.R. China-264209
}

\begin{abstract}
The present study reports the green synthesis of Zinc Oxide nanoparticles using the aqueous leaf extract Nyctanthes arbor-tristisis by co-precipitation method. The synthesized zinc oxide nanoparticles are characterized by X-Ray diffraction (XRD), Fourier Transform Infrared Spectral Analysis (FTIR), UV-Visible spectroscopy (UV-Vis), Scanning Electron Microscopy (SEM) and Energy dispersive X-Ray Analysis (EDX). The Zinc Oxide nanoparticle are crystalline in nature and have hexagonal structure with the particle size of about $25 \mathrm{~nm}$ and is determined by XRD analysis. The capping agent and the functional groups of the Zinc Oxide nanoparticles are determined by FTIR spectral analysis. The band gap energy is about $3.18 \mathrm{eV}$ for the synthesized $\mathrm{ZnO}$ nanoparticles which is calculated by UV-Visible spectroscopy. The surface morphological structure of $\mathrm{ZnO}$ nanoparticles is spherical in shape. The EDX spectroscopy is used to determine elemental composition of $\mathrm{ZnO}$ nanoparticles. The anticancer activity of Zinc Oxide nanoparticles have high toxicity against HT-29 cell line which is determined by MTT assay. The synthesized ZnO nanoparticles have decreased cell viability from $99 \%$ to $23 \%$ with increasing concentration from 10 to $100 \mu \mathrm{g} / \mathrm{mL}$.
\end{abstract}

Keywords: Green synthesis, Zinc Oxide nanoparticles, Nyctanthes arbor-tristisis, XRD, FTIR, UVVisible, SEM, EDX and anticancer activity. 


\section{Introduction}

Nanotechnology is one of the most important research and promising new technologies of the $21^{\text {st }}$ century. A number of physical, chemical, biological and hybrid methods are employed to synthesize different types of nanoparticles [1]. The physical and chemical methods are mostly used to synthesize nanoparticles. The presence of toxic compounds in these methods limits their applications and also it costs high. Therefore to avoid the toxicity, the green methods are involved for synthesize the nanomaterials using plant materials [2-4]. The plant based materials seems to be the best candidates for large-scale biosynthesis of nanoparticles. The advantage of using green methods is safe, cost effective and eco-friendly when compared to conventional methods [5, 6]. Therefore the use of non toxic leaf extracts as reducing and stabilizing agent is also an additional advantage for the green method. The presence of biomolecules in plant leaf extract, they can act as capping and stabilizing agent during synthesis process [7].

The Zinc is a mineral which is very essential for human health and the zinc oxide nanoparticle has good biocompatibility to human cells. Among metal oxides, a zinc oxide nanoparticle (ZnO NPs) is a bio-safe material and it has wide range of applications in medical, industrial, agricultural, and environmental fields $[8,9]$. The $\mathrm{ZnO}$ nanoparticle has more significant in controlling the growth of bacteria.

Cancer is characterized by invasive and uncontrolled cell division and the spread of abnormal cells [10]. Every year thousands of people worldwide die from different types of cancer. Chemotherapy and radiotherapy are most common treatments of cancer but they evoke many serious side effects [11]. The cytotoxic agents or cancer drugs are very few and are not very efficient [12]. Alternative treatment options are very less. Medicinal plants have always been used as natural remedy for many ailments and they have been a boon for many diseases and disorders. Nanoparticles synthesizing using medicinal plants extracts further enhances their efficacy as natural drugs many folds [13-15]. In the present work, we report for the first time synthesis of ZnO NPs from leaves of Nyctanthes arbortristis.

Nyctanthes arbortristis is commonly known as night jasmine or Harshringar which is the most important medicinal plant mainly used in Ayurveda [16- 18]. The leaf extract from the plant is used for various treatments of diseases such as sciatica, arthritis, fever, asthma, diabetes, cancer. The 
phytoconstituents of plant leaf contains flavanoid, glycoside, oleanic acid, essential oils, tannic acid, carotene, friedeline, lupeol, glucose, benzoic acid have been reported for significant hair tonic, hepatoprotective, anti-leishmaniasis, anti-viral, antifungal, anti-pyretic, anti-histaminic, anti-malarial, anti-bacterial, anti-inflammatory and anti-oxidant activities [19,20]. The biologically synthesize $\mathrm{ZnO}$ nanoparticle is investigated by various characterization techniques such as X-Ray diffraction, Fourier Transform-Infrared Spectroscopy (FTIR), UV-Visible spectroscopy, Scanning Electron Microscopy and Energy Dispersive X-Ray Analysis. The cytotoxic effect is evaluated by MTT assay against colon cancer cell line (HT-29 cells).

\section{Materials and methods}

The Zinc Oxide $(\mathrm{ZnO})$ nanoparticle was synthesized by Co- precipitation method using fresh leaf extract Nyctanthes arbor-tristisis. The leaves were collected around the areas of Dharmapuri. The fresh leaf extract of Nyctanthes arbor-tristisis was boiled for $60 \mathrm{~min}$ until the color of the aqueous solution changes from watery to light yellow. Then the extract was cooled to room temperature and filtered using Whatman filter paper No. 1 . The $10 \mathrm{ml}$ of leaf extract is mixed with $0.35 \mathrm{M}$ of Zinc acetate dihydrate $(50 \mathrm{ml})$ aqueous solution which was prepared using deionized water and allowed to stir for 2 Hrs. While stirring $2 \mathrm{M}$ of $\mathrm{NaOH}(50 \mathrm{ml})$ was added inorder to maintain $\mathrm{pH}$ at 13 and was stirred for 4 Hrs. After complete stirring, the white precipitate was formed. Next, the white precipitate was rinsed repeatedly for three to four times using distilled water inorder to eliminate impurities. The precipitate was dried in an oven for $100^{\circ} \mathrm{C}$ for $3 \mathrm{Hrs}$ and the obtained particles were calcinated under a muffle furnace at $400^{\circ} \mathrm{C}$ for $3 \mathrm{Hrs}[21,22]$. Then the particle was grinded using mortar to get fine nanoparticle. The process synthesis method is shown in Figure 1.

\section{Characterization Techniques}

The crystalline nature of $\mathrm{ZnO}$ nanoparticle is studied using $\mathrm{X}$-Ray diffraction (Shimadzu XRD 6000 X-Ray diffractometer). The capping molecules and the functional groups are tested in Fourier Transform Infrared Spectroscopy (FTIR) using PerkinElmer. The optical properties of $\mathrm{ZnO}$ nanoparticle is characterized by a PerkinElmer Lambda 35 and the spectrum is recorded the wavelengths from 200 to $800 \mathrm{~nm}$. The high resolution imaging and morphological structure of $\mathrm{ZnO}$ nanoparticles are determined by Scanning Electron Microscopy using the instrument Jeol JSM 6390. The Energy Dispersive X-Ray analysis is used to analyze elemental composition and stoichiometric mass percentage of $\mathrm{ZnO}$ nanoparticles (EV018, Carl Zeiss). 


\subsection{Anticancer activity}

The $\mathrm{ZnO}$ nanoparticle is tested for anticancer using HT-29 cells by 3-(4, 5dimethylthiazol-2-yl)-2, 5-diphenyltetrazolium bromide (MTT) assay. Briefly, the cultured HT-29 cells are harvested by trypsinization, pooled in a $15 \mathrm{ml}$ tube. Then, the cells are plated at a density of $1 \times 10^{5}$ cells $/ \mathrm{ml}$ cells/well $(200 \mu \mathrm{L})$ into the 96 -well tissue culture plate in DMEM medium containing $10 \% \mathrm{FBS}$ and $1 \%$ antibiotic solution for $24-48 \mathrm{Hrs}$ at $37^{\circ} \mathrm{C}$. The wells are washed with sterile PBS and treated with various concentrations of the $\mathrm{ZnO}$ nanoparticle in a serum free DMEM medium. Each sample is replicated three times and the cells are incubated at $37^{\circ} \mathrm{C}$ in a humidified $5 \% \mathrm{CO}_{2}$ incubator for $24 \mathrm{Hrs}$. After the incubation period, MTT ( $20 \mu \mathrm{L}$ of $5 \mathrm{mg} / \mathrm{ml})$ is added into each well and the cells incubated for another 2-4 Hrs until purple precipitates are clearly visible under an inverted microscope. Finally, the medium together with MTT $(220 \mu \mathrm{L})$ are aspirated off the wells and washed with $1 \mathrm{X}$ PBS $(200 \mu \mathrm{l})$. Furthermore, to dissolve formazan crystals, DMSO $(100 \mu \mathrm{L})$ is added and the plate is shaken for $5 \mathrm{~min}$. The absorbance of each well is measured at $570 \mathrm{~nm}$ using a micro plate reader (Thermo Fisher Scientific, USA) and the percentage cell viability and $\mathrm{IC}_{50}$ value is calculated using GraphPad Prism 6.0 software (USA) [23].

\section{Result and Discussion}

\subsection{X-Ray diffraction}

The XRD is used to determine the particle size or the grain size of the zinc oxide nanoparticle. The $\mathrm{ZnO}$ nanoparticles are found to be hexagonal and matched with JCPDS card no.79-2205 [24]. From the Figure 2, the typical diffractions of (100), (002), (101), (102), (110), (103), (200) and (112) are attributed to $\mathrm{ZnO}$ nanoparticle and the maximum detection of (101) at the angle $36^{\circ}$ is determined [25].The particle size of the $\mathrm{ZnO}$ nanoparticle is calculated using Scherrer's equation.

$$
D=\frac{\mathrm{k} \lambda}{\beta \operatorname{Cos} \theta} \mathrm{nm}
$$

Where $\mathrm{k}=$ Scherrer's constant $(0.9), \lambda=$ Wavelength of X-ray $\left(1.54 \times 10^{-10} \mathrm{~m}\right), \beta=$ Full Width at Half Maximum (FWHM), $\theta=$ Bragg's angle.

From the Table 1, it shows that the values of particle size for the $\mathrm{ZnO}$ nanoparticles are calculated from the above equation using three strongest peaks. Therefore the average particle size is $25 \mathrm{~nm}$ for the $\mathrm{ZnO}$ nanoparticle using Nyctanthes arbor-tristis leaf extract. 
The particle size of the $\mathrm{ZnO}$ nanoparticle indicates more crystalline in nature which also confirmed theoretically using Scherrer's equation.

\subsection{Fourier Transform Infrared Spectral Analysis (FTIR)}

The Figure 3 shows the FTIR spectrum of zinc oxide nanoparticles using Nyctanthes arbortristis leaf extract and ranges from $4000 \mathrm{~cm}^{-1}-400 \mathrm{~cm}^{-1}$. The FTIR spectrum is used to investigate the functional groups presents in $\mathrm{ZnO}$ nanoparticles with capping agent of leaf extract Nyctanthes arbortristis. The biomolecules present in the leaf extract which is responsible of reducing and capping agent for the $\mathrm{ZnO}$ nanoparticle. The FTIR spectrum shows the strongest peak at $3441.89 \mathrm{~cm}^{-1}$ indicates hydroxyl functional groups in alcohol and phenolic compounds. The peak at 490.48 $\mathrm{cm}^{-1}$ confirms the presence of $\mathrm{ZnO}$ nanoparticles. The peak at $2924.65 \mathrm{~cm}^{-1}$ is due to the aromatic $\mathrm{C}-\mathrm{H}$ stretching vibration. The peak around at $1632.59 \mathrm{~cm}^{-1}$ is assigned to carbonyl and carboxylic $(\mathrm{C}=\mathrm{O})$ stretching bands of peptide linkages. The absorption band at $1549.30 \mathrm{~cm}^{-1}$ is attributed to $\mathrm{N}-\mathrm{H}$ bending vibration. The peaks at $1436.48 \mathrm{~cm}^{-1}$ and $1110.28 \mathrm{~cm}^{-1}$ are due to $\mathrm{C}-\mathrm{C}$ and $\mathrm{C}-\mathrm{N}$ stretching vibration respectively. The aromatic $\mathrm{C}-\mathrm{H}$ bending vibration is observed at $841.21 \mathrm{~cm}^{-1}$ [26, 27]. The presence of Nyctanthes arbor-tristis leaf extract is considered as the capping ligands which gives the stability to the $\mathrm{ZnO}$ nanoparticles.

\subsection{UV-Visible spectroscopy}

The UV-Visible spectroscopy is used to determine the optical properties and has wide range of applications in biomedical science [28]. The zinc oxide nanoparticles have attracted great attention towards the optical properties. The UV absorption spectrum of $\mathrm{ZnO}$ nanoparticle shows the strongest absorption peak at $391.31 \mathrm{~nm}$ and the binding gap energy is $3.18 \mathrm{eV}$. The color of the $\mathrm{ZnO}$ nanoparticles is white in color due to its surface plasmon resonance which confirms that the solution is free from impurities. The Figure 4 shows the absorption peak of $\mathrm{ZnO}$ nanoparticle using Nyctanthes arbor-tristis leaf extract.

\subsection{Scanning Electron Microscopy}

The scanning electron microscopy is used to determine the surface morphology and shape of the $\mathrm{ZnO}$ nanoparticles. The micrographs of $\mathrm{ZnO}$ nanoparticles using fresh leaf extract Nyctanthes arbor-tristis are shown in Figure 5. The precursor is used as zinc acetate then the zinc oxide 
molecules are grown slowly, forms spherical shape and also agglomeration in the nanoparticles. The SEM results that the $\mathrm{ZnO}$ nanoparticles are uniformly distributed and they are in spherical shape [29].

\subsection{Energy Dispersive X-Ray analysis (EDX)}

The elemental composition of the $\mathrm{ZnO}$ nanoparticles is determined by EDX analysis. The Figure 6 shows the single peak of zinc and oxygen is present between 0 and 2. The two peaks of zinc are present between 8 and 10 [30]. The presence of elements in the sample confirms that the nanoparticles are formed high purity without any external disturbance. The stoichiometric mass percentage of zinc and oxygen are $66 \%$ and $34 \%$ respectively and is shown in Table 2.

\subsection{Anticancer activity of green synthesized nanoparticles}

The anticancer activity of $\mathrm{ZnO}$ nanoparticles are performed by MTT assay. The cell viability assay is one of the most important parameter which gives more information about survival and death cells [31]. The cell viability of synthesized $\mathrm{ZnO}$ nanoparticles using fresh leaf extract Nyctanthes arbor-tristis against HT-29 cell lines for different concentrations is shown in Figure 7. The HT-29 cell lines are treated with different concentrations which ranges from 10 to $100 \mu \mathrm{g} / \mathrm{mL}$ to assess the percentage of cell viability. The cell viability of HT-29 cell lines is decreased with increasing concentration of $\mathrm{ZnO}$ nanoparticles from 10 to $100 \mu \mathrm{g} / \mathrm{mL}$ which are given in Table 3. The synthesized $\mathrm{ZnO}$ nanoparticles have decreased cell viability from $99 \%$ to $23 \%$. The half maximal inhibitory concentration of the $\mathrm{ZnO}$ nanoparticles has $61 \%$ of cell viability at $\mathrm{IC}_{50}$. This result clearly indicates that the $\mathrm{ZnO}$ nanoparticles have highly cytotoxic effect against HT-29 cell lines [32]. The microscopic images of green synthesis of $\mathrm{ZnO}$ nanoparticles using fresh leaf extract Nyctanthes arbor-tristis against HT-29 cell lines is shown in Figure 8.

\section{Conclusion}

The simple and economical green methods are used to synthesize $\mathrm{ZnO}$ nanoparticles using fresh leaf extract of Nyctanthes arbor-tristis. The ZnO nanoparticles are characterized by XRD, FTIR, UVVisible, SEM and EDX. The X-Ray diffraction proved that the $\mathrm{ZnO}$ nanoparticles are crystalline in nature and particle size is about $25 \mathrm{~nm}$. The peak at $490.48 \mathrm{~cm}^{-1}$ confirms the presence of $\mathrm{ZnO}$ nanoparticles. The absorption peak at $391.31 \mathrm{~nm}$ clearly indicates the synthesis of $\mathrm{ZnO}$ nanoparticles along with formation of white color which indicates that the particle is free from 
impurities. The surface of the $\mathrm{ZnO}$ nanoparticles is spherical shape which is analyzed by SEM. The stoichiometric mass percentage of zinc and oxygen is $66 \%$ and $34 \%$ respectively which is determined by EDX spectrum. The ZnO nanoparticles show the cell viability of HT-29 cell lines decreased with increase concentration. Hence the green synthesized $\mathrm{ZnO}$ nanoparticles have great advantage of less toxicity, low cost and good biocompatibility.

\section{References}

1. B. Malaikozhundan, B. Vaseeharan, S. Vijayakumar, K. Pandiselvi, M. A. R. Kalanjiam, K. Murugan, G. Benelli (2017). Biological therapeutics of Pongamia pinnata coated zinc oxide nanoparticles against clinically important pathogenic bacteria, fungi and $\mathrm{MCF}-7$ breast cancer cells. Microbial pathogenesis, 104, 268-277.

2. O. V. Kharissova, H. R. Dias, B. I. Kharisov,B. O. Pérez \& V. M. J. Pérez (2013). The greener synthesis of nanoparticles. Trends in biotechnology, 31(4), 240-248.

3. S. M. Ouda (2014). Antifungal activity of silver and copper nanoparticles on two plant pathogens, Alternaria alternata and Botrytis cinerea. Research Journal of Microbiology, 9(1), 34.

4. S. Vanaraj, B.B. Keerthana \& K. Preethi (2017). Biosynthesis, characterization of silver nanoparticles using quercetin from Clitoria ternatea $\mathrm{L}$ to enhance toxicity against bacterial biofilm. Journal of Inorganic and Organometallic Polymers and Materials, 27(5), 1412-1422.

5. M.A. Ansari \& M.A. Alzohairy (2018). One-pot facile green synthesis of silver nanoparticles using seed extract of Phoenix dactylifera and their bactericidal potential against MRSA. Evidence-Based Complementary and Alternative Medicine, 2018.

6. S.G. Ali, M.A. Ansari, H.M. Khan, M. Jalal, A.A. Mahdi \& S.S. Cameotra (2018). Antibacterial and antibiofilm potential of green synthesized silver nanoparticles against imipenem resistant clinical isolates of $P$. aeruginosa. BioNanoScience, 8(2), 544-553.

7. A. Abdelkhalek, A.A. Al-Askar (2020). Green synthesized ZnO nanoparticles mediated by Mentha Spicata extract induce plant systemic resistance against Tobacco mosaic virus. Applied Sciences, 10(15), 5054.

8. A. Kołodziejczak-Radzimska \& T. Jesionowski (2014). Zinc oxide-from synthesis to application: a review. Materials, 7(4), 2833-2881. 
9. A. Ali, S. Ambreen, R. Javed, S. Tabassum, I. Ul Haq \& M. Zia (2017). ZnO nanostructure fabrication in different solvents transforms physio-chemical, biological and photodegradable properties. Materials Science and Engineering: C, 74, 137-145.

10. D.D. Gan, M. Macaluso, C.Cinti, K. Khalili \& A. Giordano (2003). How does a normal human cell become a cancer cell? Journal of experimental \& clinical cancer research: CR, 22(4), 509-516.

11. C.E. De Santis, C.C Lin, A.B. Mariotto, R.L. Siegel, K.D. Stein \& J.L. Kramer (2014). Cancer treatment and survivorship statistic. CA Cancer J Clin 64:252-271.

12. J.S. Kim, E. Kuk, K.N. Yu, J.H. Kim, S.J. Park, H.J. Lee \& M.H. Cho (2007). Antimicrobial effects of silver nanoparticles. Nanomedicine: Nanotechnology, Biology and Medicine, 3(1), 95-101.

13. A.M. Awwad, B. Albiss \& S.L. Ahmad (2014). Green synthesis characterization and optical properties of zinc oxide nanosheets using Olea europea leaf extract. Adv Mater Lett. 5:520524.

14. V. Anbukkarasi, R. Srinivasan \& N. Elangovan (2015). Antimicrobial activity of green synthesized zinc oxide nanoparticles from Emblica officinalis. Int J Pharmaceu Sci Rev Res. $33: 110-115$.

15. P.C. Nagajyothi, S.J.Cha, I.J.Yang, T.V. M. Sreekanth, K.J. Kim \& H.M. Shin (2015). Antioxidant and anti-inflammatory activities of zinc oxide nanoparticles synthesized using Polygala tenuifolia root extract. Journal of Photochemistry and Photobiology B: Biology, 146, $10-17$.

16. P. Velmurugan, J.H. Park, S.M. Lee, Y.J. Yi, M. Cho, J.S. Jang \& B.T. Oh (2016). Ecofriendly approach towards green synthesis of zinc oxide nanocrystals and its potential applications. Artificial cells, nanomedicine, and biotechnology, 44(6), 1537-1543.

17. J. Agrawal \& A. Pal (2013). Nyctanthes arbor-tristis Linn-A critical ethnopharmacological review. Journal of ethnopharmacology, 146(3), 645-658.

18. R.K. Das, N. Gogoi \& U. Bora (2011). Green synthesis of gold nanoparticles using Nyctanthes arbortristis flower extract. Bioprocess and biosystems engineering, 34(5), 615619.

19. M. Sundrarajan \& S. Gowri (2011). Green synthesis of titanium dioxide nanoparticles by Nyctanthes arbor-tristis leaves extract. Chalcogenide Lett, 8(8), 447-451 
20. R. Shrivastava \& B. AK (2018). Nyctanthes arbortristis an Important Medicinal Plant of Madhya Pradesh State: A Review. UK J Phar Bios, 6(6), 10-5.

21. K. Shreema, V. Kalaiselvi \& R. Mathammal (2020). Green synthesis and characterization of zinc oxide nanoparticles using leaf extract of evolvulus alsinoides. Studies in Indian Place Names, 40(18), 763-778.

22. K.Shreema, V.Kalaiselvi, K. Priyadharshini \& R.Mathammal (2020).Green synthesis of Zinc Oxide Nanoparticles Using Leaf Extract of Salvia officinalis. Studies in Indian Place Names, 40(18), 1175-1187

23. S. Ganapaty, G.V.K. Srilakshmi, P.S. Thomas, N.R. Rajeswari \& S. Ramakrishna (2009). Cytotoxicity and antiprotozoal activity of flavonoids from three Tephrosia species. Journal of Natural Remedies, 9(2), 202-208.

24. S. Vijayakumar, C. Krishnakumar, P. Arulmozhi, S. Mahadevan \& N. Parameswari (2018). Biosynthesis, characterization and antimicrobial activities of zinc oxide nanoparticles from leaf extract of Glycosmis pentaphylla (Retz.) DC. Microbial pathogenesis, 116, 44-48.

25. S. Vijayakumar (2018). Green synthesis of Zinc Oxide nanoparticles using Atalantia monophylla leaf extracts: Characterization and antimicrobial analysis. Materials Science in Semiconductor Processing 82: 39-45.

26. S. Vijayakumar, B. Vaseeharan, B. Malaikozhundan \& M. Shobiya (2016). Laurus nobilis leaf extract mediated green synthesis of $\mathrm{ZnO}$ nanoparticles: characterization and biomedical applications. Biomedicine \& Pharmacotherapy, 84, 1213-1222.

27. A. Sanmugam, D. Vikraman, S. Venkatesan \& H.J.Park (2017). Optical and structural properties of solvent free synthesized starch/chitosan-ZnO nanocomposites. Journal of Nanomaterials.

28. S. Vijayakumar, G. Vinoj, B. Malaikozhundan, S. Shanthi \& B. Vaseeharan (2015). Plectranthus amboinicus leaf extract mediated synthesis of zinc oxide nanoparticles and its control of methicillin resistant Staphylococcus aureus biofilm and blood sucking mosquito larvae. Spectrochimica Acta Part A: Molecular and Biomolecular Spectroscopy, 137, 886891.

29. E. Burstein. (1954). Anomalous optical absorption limit in InSb. Physical Review, 93(3), 632.

30. C. Abinaya, M. Marikkannan, M. Manikandan, J. Mayandi, P. Suresh, V. Shanmugaiah \& J. M. Pearce (2016). Structural and optical characterization and efficacy of hydrothermal 
synthesized $\mathrm{Cu}$ and $\mathrm{Ag}$ doped zinc oxide nanoplate bactericides. Materials Chemistry and Physics, 184, 172-182.

31. H. Padalia \& S. Chanda (2017). Characterization, antifungal and cytotoxic evaluation of green synthesized zinc oxide nanoparticles using Ziziphus nummularia leaf extract. Artificial cells, nanomedicine, and biotechnology, 45(8), 1751-1761.

32. Z. Heidari, A. Salehzadeh, S. A. S. Shandiz \& S. Tajdoost (2018). Anti-cancer and antioxidant properties of ethanolic leaf extract of Thymus vulgaris and its bio-functionalized silver nanoparticles. 3 Biotech, 8(3), 1-14.

Figure1: The systematic representation of preparing $\mathrm{ZnO}$ nanoparticles

Figure 2: The XRD analysis of $\mathrm{ZnO}$ nanoparticle using leaf extract Nyctanthes arbor-tristis

Figure 3: The FTIR spectrum of $\mathrm{ZnO}$ nanoparticle using Nyctanthes arbor-tristis leaf extract

Figure 4: The UV-Visible spectroscopy of $\mathrm{ZnO}$ nanoparticle using Nyctanthes arbor-tristis leaf extract

Figure 5: The SEM micrographs of $\mathrm{ZnO}$ nanoparticles using Nyctanthes arbor-tristis leaf extract.

Figure 6: The EDX spectrum of $\mathrm{ZnO}$ nanoparticles using aqueous leaf extract Nyctanthes arbortristis.

Figure 7: The cell viability of synthesized $\mathrm{ZnO}$ nanoparticles using fresh leaf extract Nyctanthes arbor-tristis against HT-29 cell lines for different concentrations

Figure 8: The microscopic images of green synthesis of $\mathrm{ZnO}$ nanoparticles using fresh leaf extract Nyctanthes arbor-tristis against HT-29 cell lines.

Table 1: The particle size of $\mathrm{ZnO}$ nanoparticle for the three strongest peaks.

Table 2: The stoichiometric mass percentage of Zinc and oxygen using fresh leaf extract Nyctanthes arbor-tristis

Table 3: Cell viability of $\mathrm{ZnO}$ nanoparticles 


\section{Figures}

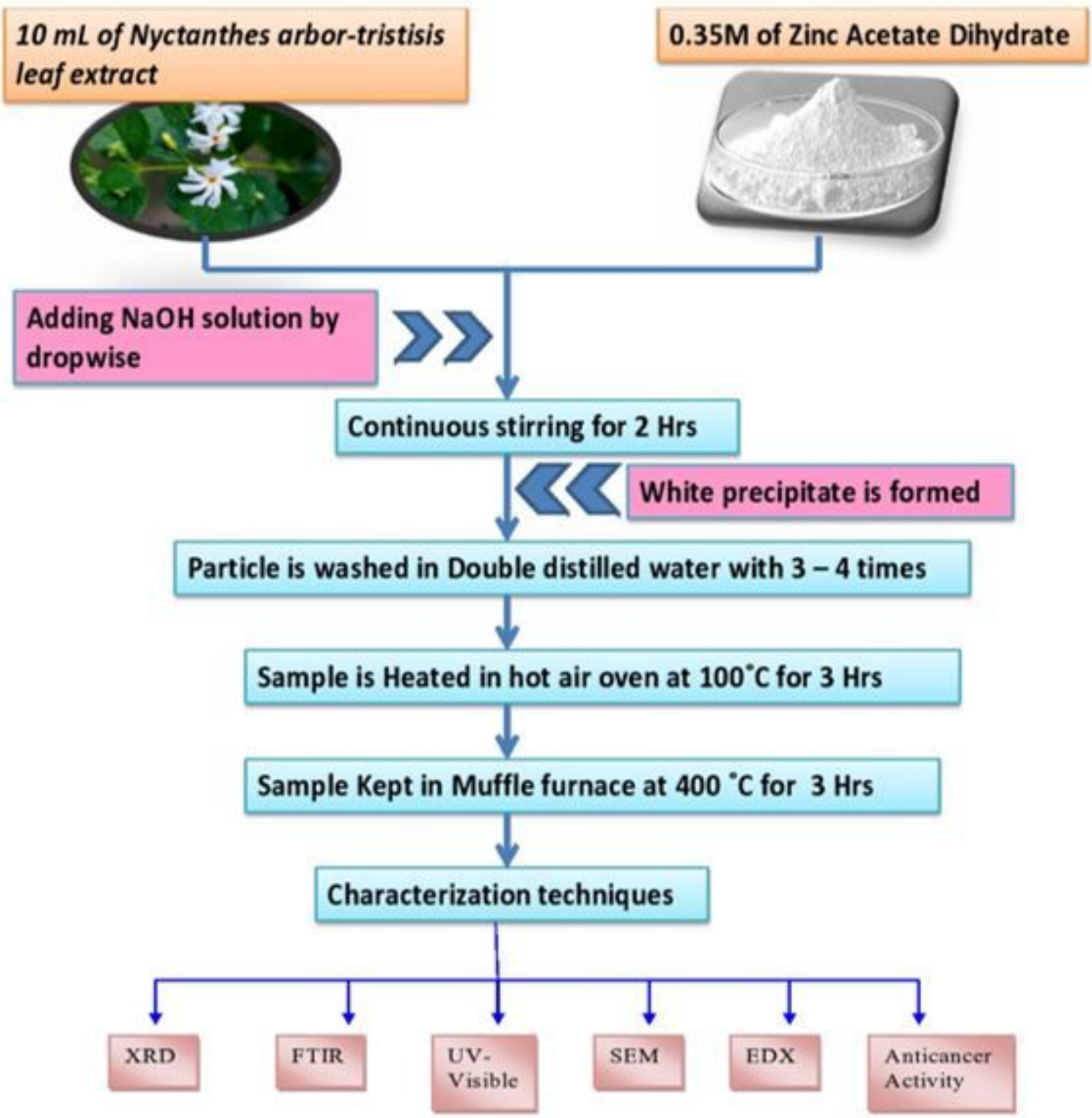

Figure 1

The systematic representation of preparing $\mathrm{ZnO}$ nanoparticles 


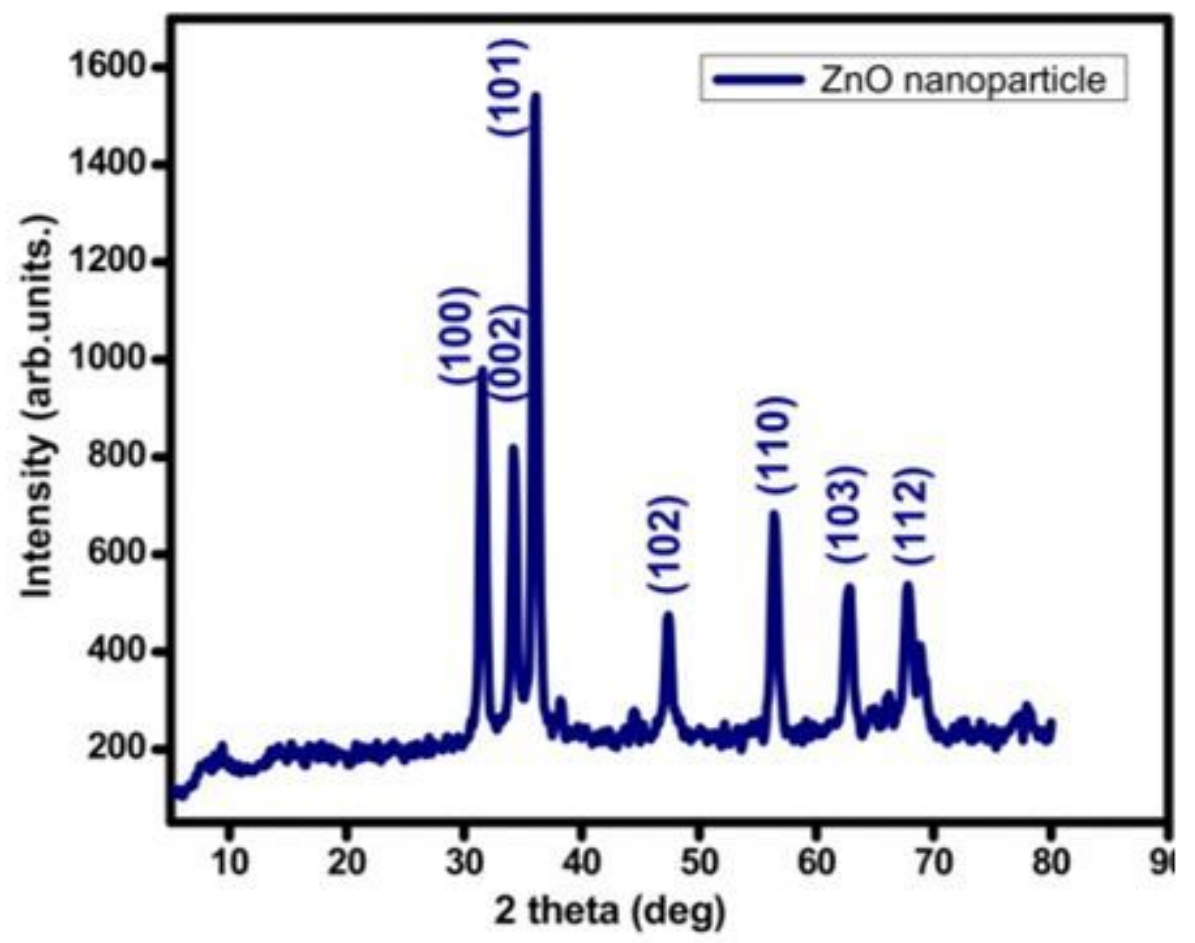

Figure 2

The XRD analysis of ZnO nanoparticle using leaf extract Nyctanthes arbor-tristis 


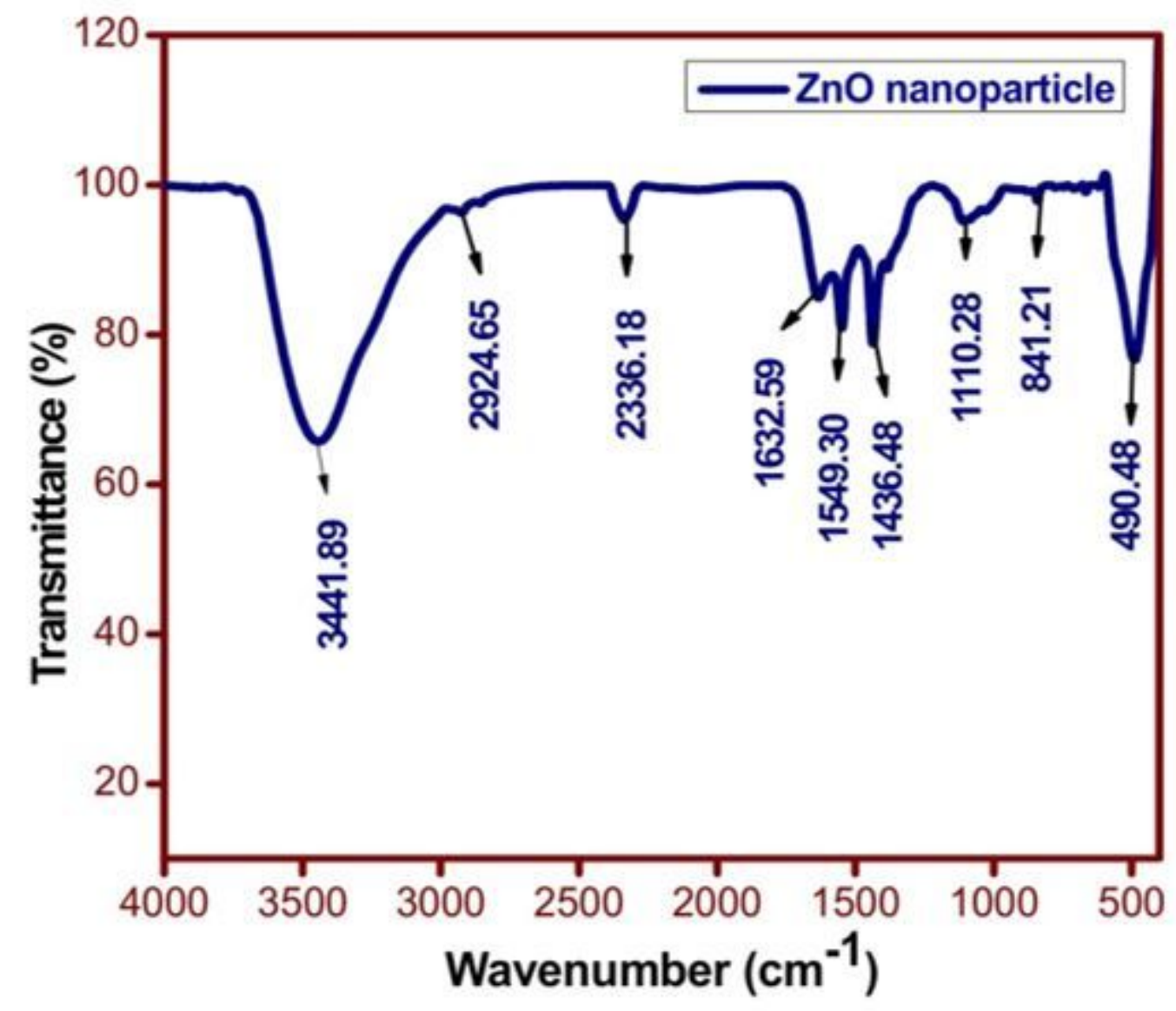

Figure 3

The FTIR spectrum of ZnO nanoparticle using Nyctanthes arbor-tristis leaf extract 


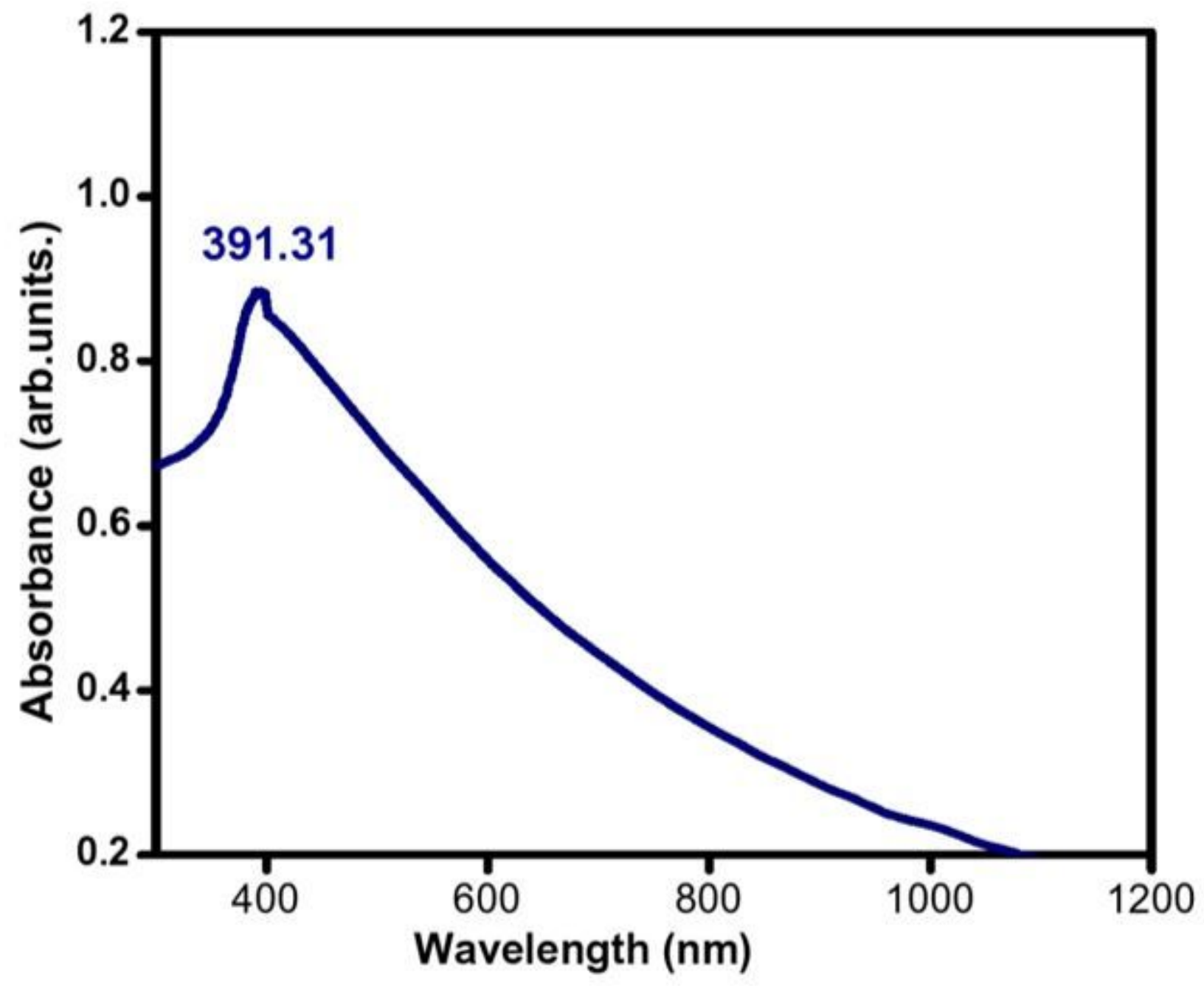

Figure 4

The UV-Visible spectroscopy of ZnO nanoparticle using Nyctanthes arbor-tristis leaf extract 

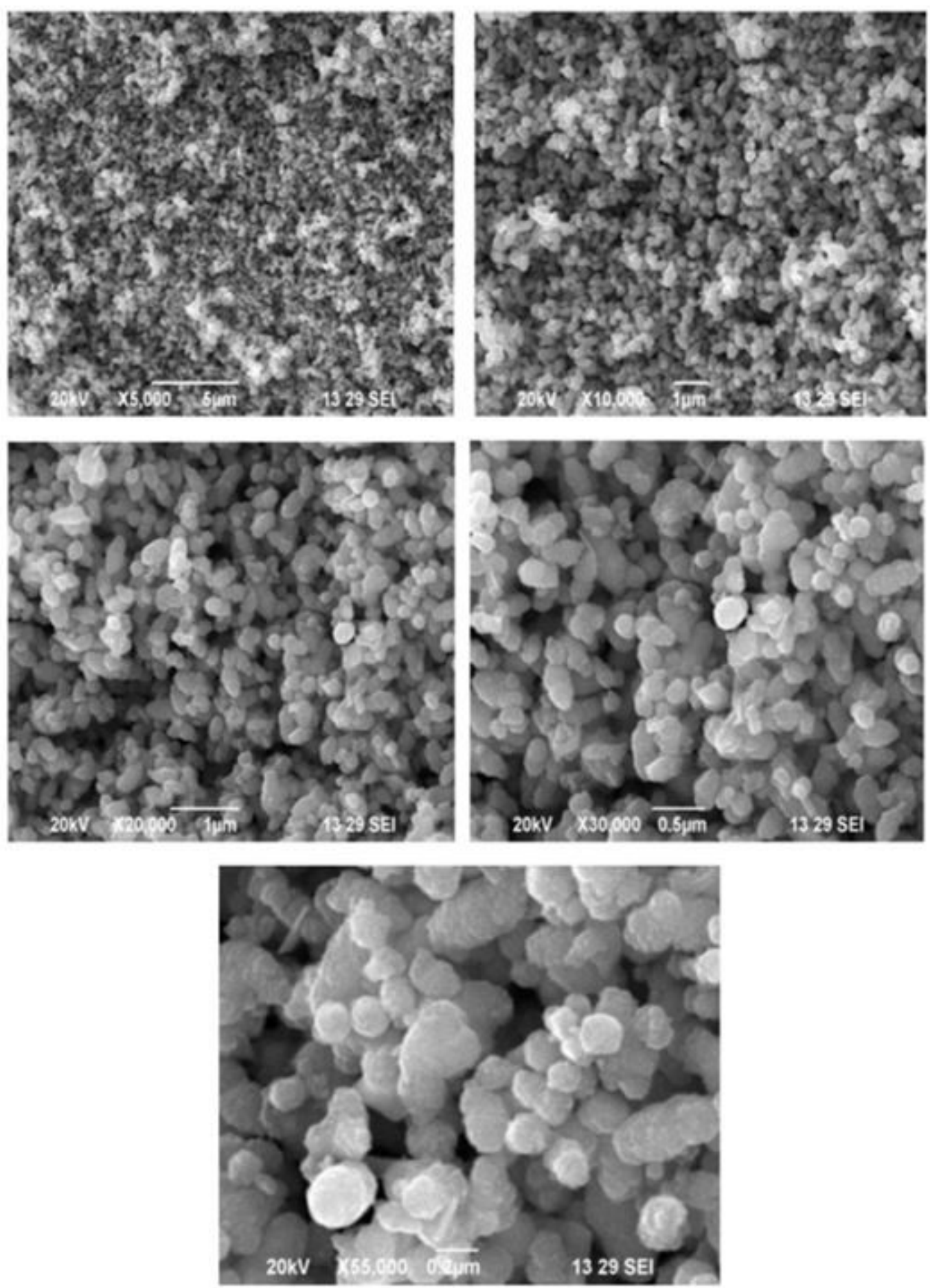

Figure 5

The SEM micrographs of $\mathrm{ZnO}$ nanoparticles using Nyctanthes arbor-tristis leaf extract. 


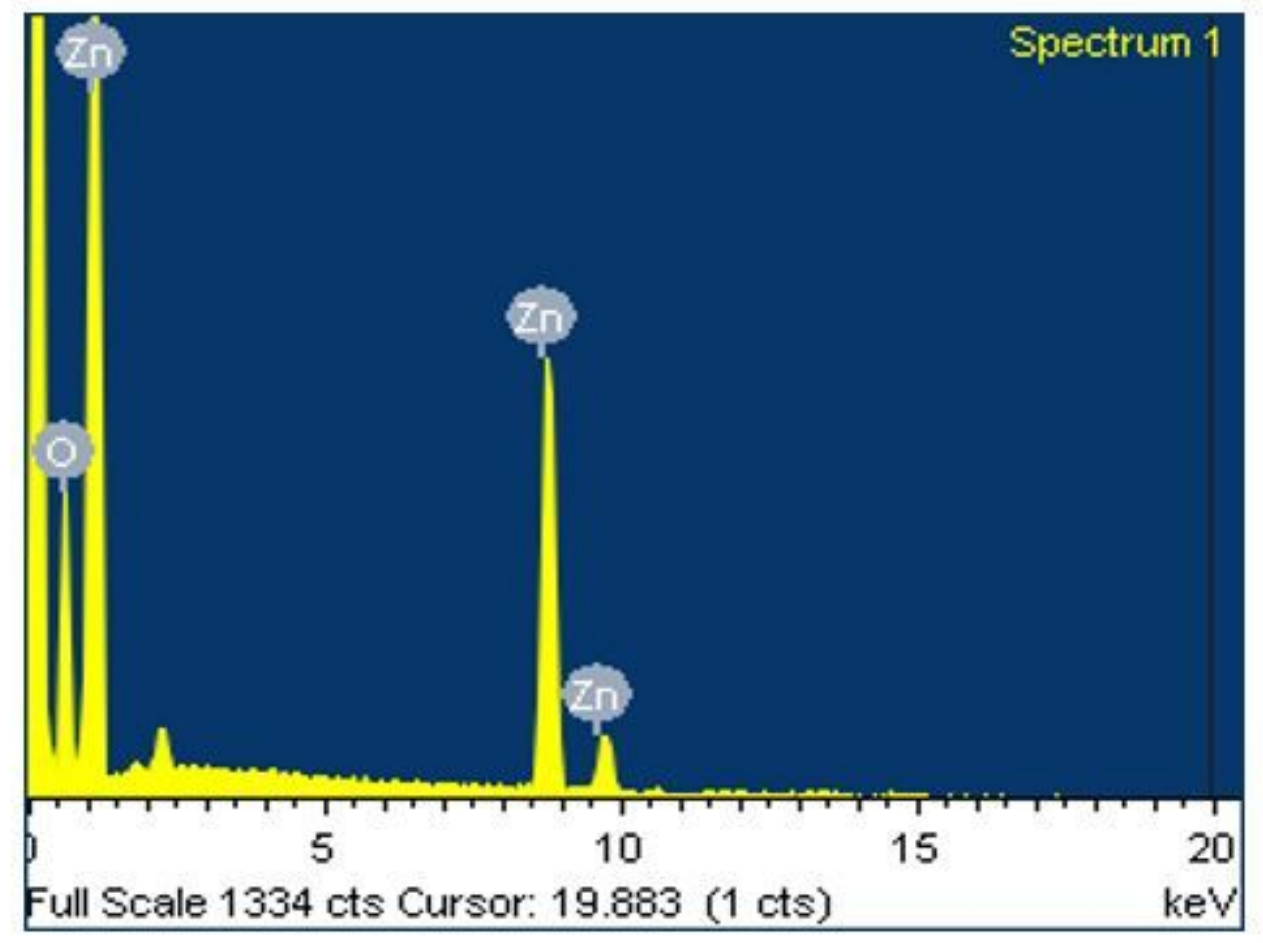

Figure 6

The EDX spectrum of ZnO nanoparticles using aqueous leaf extract Nyctanthes arbor-tristis.

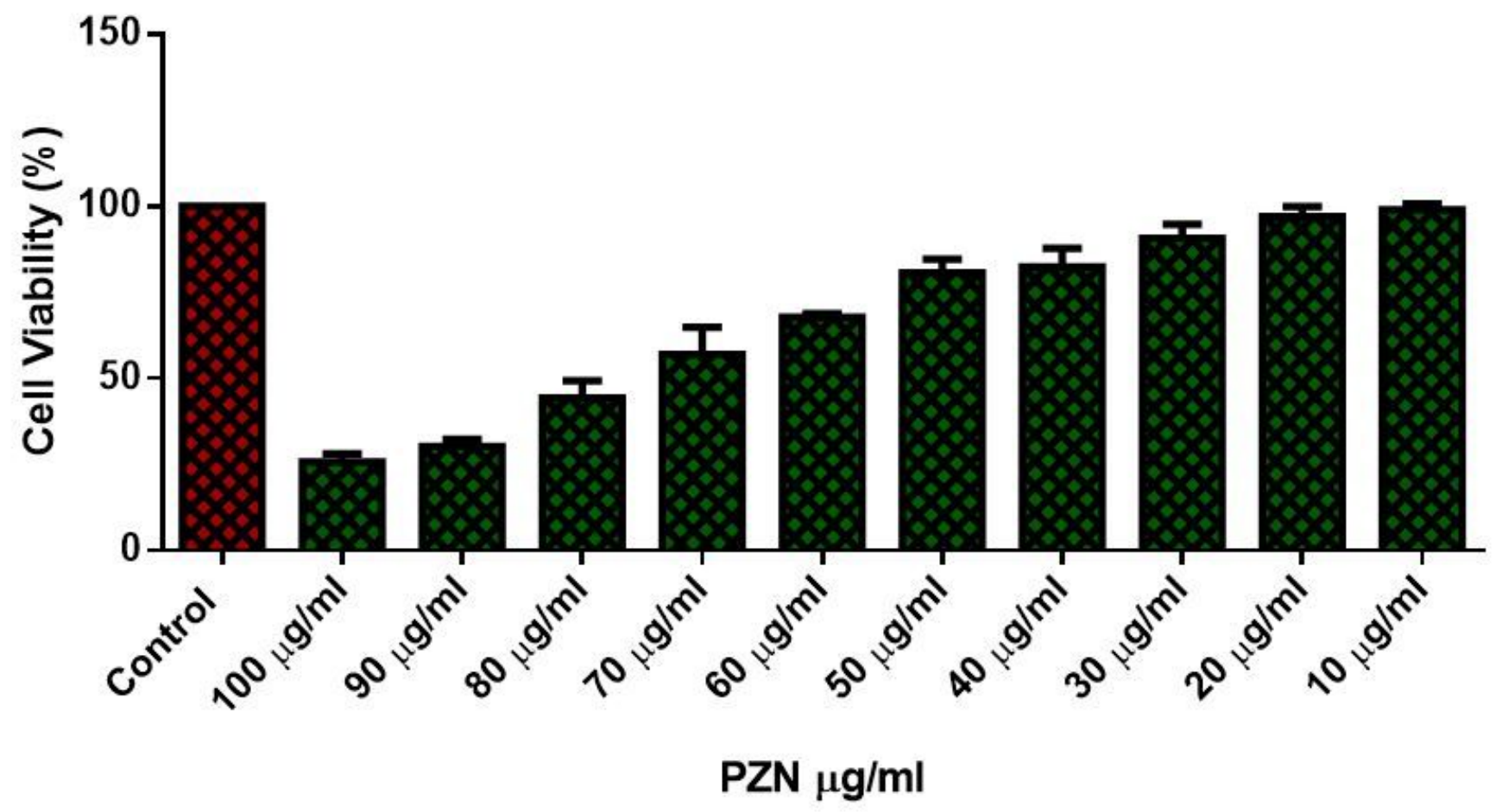




\section{Figure 7}

The cell viability of synthesized $\mathrm{ZnO}$ nanoparticles using fresh leaf extract Nyctanthes arbor-tristis against HT-29 cell lines for different concentrations

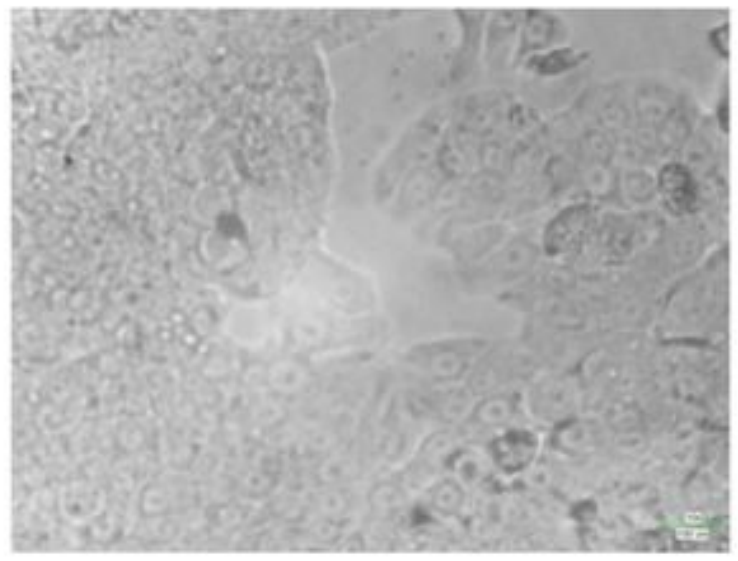

Control cells

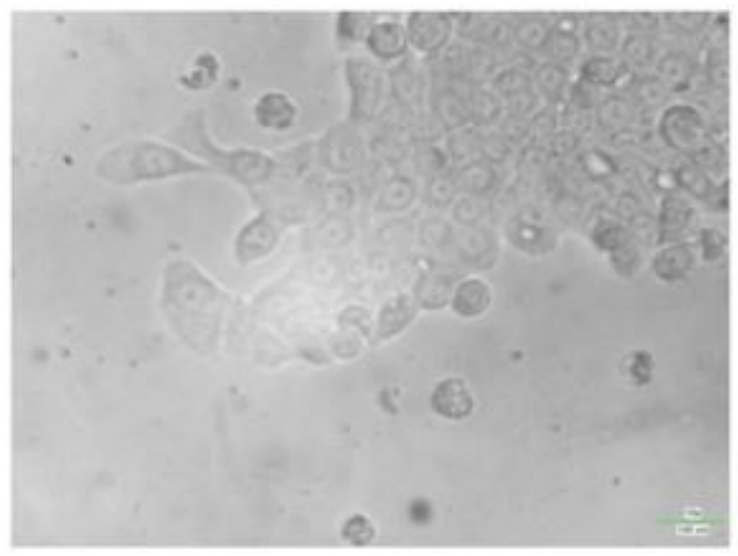

Sample $70 \mu \mathrm{g} / \mathrm{ml}$

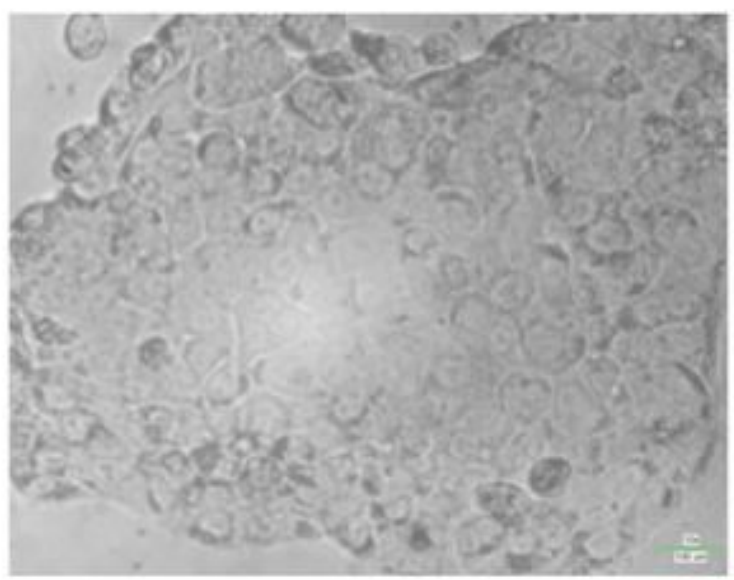

Sample $30 \mu \mathrm{g} / \mathrm{ml}$

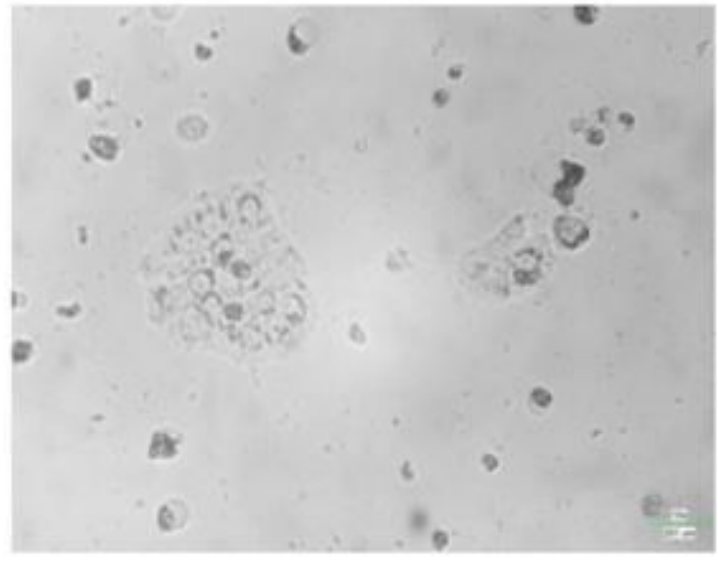

Sample $100 \mu \mathrm{g} / \mathrm{ml}$

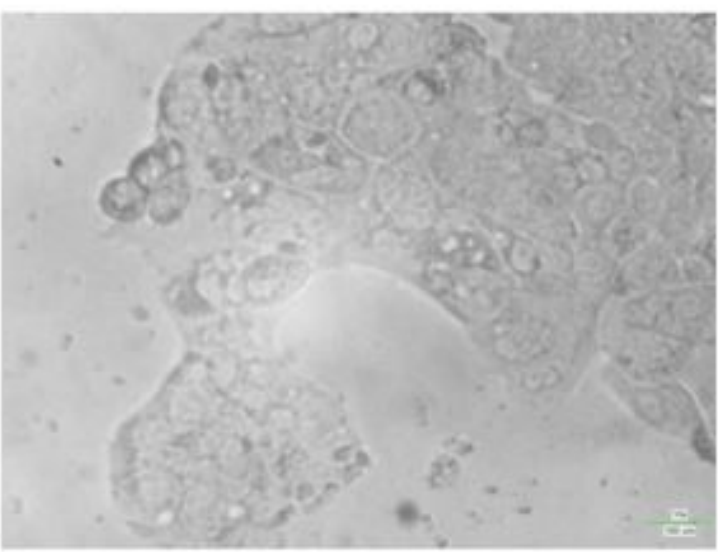

Sample $50 \mu \mathrm{g} / \mathrm{ml}$

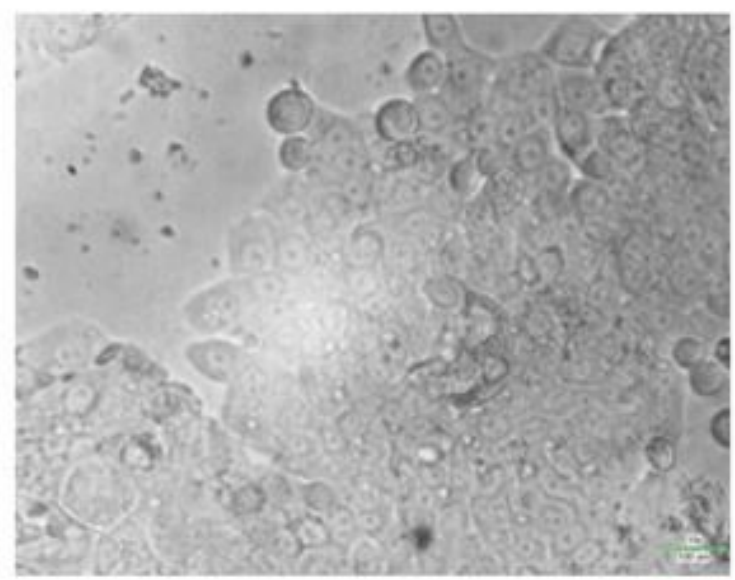

Sample $10 \mu \mathrm{g} / \mathrm{ml}$

Figure 8 
The microscopic images of green synthesis of $\mathrm{ZnO}$ nanoparticles using fresh leaf extract Nyctanthes arbor-tristis against HT-29 cell lines. 